UDK 528.9

\title{
LIETUVOS EŽERŲ PAVADINIMŲ POKYČIAI SKIRTINGO LAIKMEČIO KARTOGRAFINĖJE MEDŽIAGOJE
}

\author{
Romualdas Girkus \\ Aerogeodezijos institutas \\ Pramonès pr. 13, LT-51382 Kaunas-31, el.paštas: info @agi.lt \\ Viktoras Lukoševičius \\ KTU, Panevěžio institutas \\ Nemuno 33,LT-35209 Panevėžys, el.paštas: vikluk@midi.ppf.ktu.lt
}

Iteikta 200310 09; priimta 20040614

\begin{abstract}
Santrauka. Pirmieji lietuviški Lietuvos teritorijos topografiniai žemėlapiai buvo išleisti iki Antrojo pasaulinio karo. Sovietmečiu dèl Lietuvos hidrografijos pertvarkos melioracijos ir hidroenergetikos reikmèms vietovè gerokai pakito. Straipsnyje analizuojami esminiai ežerų bei jų vardų pokyčiai, palyginti su antriniu Lietuvos teritorijos topografiniu kartografavimu, pradètu atgavus nepriklausomybę. Nagrinėjamos ežerų vardų norminimo problemos ir teikiama dviejų kartografavimų ežerų vardų esminių pokyčių lentelè.
\end{abstract}

Raktažodžiai: topografinis kartografavimas, interpretavimas, vietovardžių norminimas.

\section{Ivadas}

Lietuvos pagrindinès teritorijos $\quad(\approx 2 / 3$ ploto $)$ lietuviškieji topografiniai M 1: 100000 žemėlapiai buvo sudaryti iki Antrojo pasaulinio karo (toliau tekste pirminis kartografavimas). Nebuvo spèta sudaryti Lietuvos pasienio, tarp jų ir Lenkijos okupuotos Lietuvos teritorijos, žemėlapių. Sovietmečiu Lietuvos teritorijos žemėlapiai buvo rusų kalba. Antraji kartą Lietuvos teritorijos lietuviškuosius gretimo 1:50 000 mastelio topografinius žemėlapius (toliau tekste - antrinis kartografavimas) pradèta sudaryti atgavus nepriklausomybę, ir darbas beveik baigiamas. Todèl imanoma atlikti šių kartografavimo etapų informacijos požiūriu lyginimą.

Teritorijai kartografuoti paprastai naudojama nauja aeronuotrauka. Ši informacija, pateikta ortogonaliojoje projekcijoje, remiantis turima kartografine medžiaga interpretuojama. Tarp abiejų lietuviškų topografinių žemėlapių laidų truko sovietmečio periodas, - pirmosios laidos lietuviškieji žemèlapiai buvo užslaptinti ir, atliekant Lietuvos teritorijos kartografavimą, nebuvo naudojami. Antrinis kartografavimas vyko naudojant rusu kalba išleistų žemèlapių informaciją. Nors juose vietovès pokyčiai fiksuoti, tačiau lietuviški vietovardžiai buvo sudarkyti, netiksliai juos transkribuojant ị rusų kalbą.

\section{Esminiai ežerų pokyčiai}

1959 m. Kauno hidroelektrinei patvenkus Nemuną, Kauno marios užliejo apie 0,1\% Lietuvos teritorijos 63,5 kv. km. ploto. Pakèlus vandens lygi Nemune apie 16 metrų buvo užlieta apie 20 kaimų, tačiau kadangi ši teritorija ne itin ežeringa, inventorizuotų ívardytų ežerų neprarasta. Kauno marių vidurinè dalis nuo Strèvos upès žiočių iki Darsūniškio su siauromis stačiašlaitėmis ¡llankèlèmis-estuarijomis tik primena rininius ežerus, „,ežeru“" kraštovaizdi [1].

Daugiausia ežeru prarasta 1959 m. ties Antaliepte patvenkus Šventają. Hidroelektrinès reikmėms susidarè 1911 ha Antalieptès tvenkinys, kuris apsėmé arba patvenkè 26 ežerus [2]. Kai kurių ežerų vandens lygis pakilo net keletą metru, tad dauguma jų susijungè $i$ bendrą tvenkini ir tik kai kurių išliko atskiri nuo tvenkinio krantai (Uolys, Lydekis, Sniegiškis). Išnyko arba pakito šie ežerai: Dusetas (390 ha), Diegis (89 ha), Jūžintas (79 ha), Uolys (60 ha), Abisavas (49 ha), Zazubras (40 ha), Salakas (36 ha), Armelis (22 ha), Skrindelis (20 ha), Liminas (8 ha), Limenis (7 ha), Liminèlis (5 ha), Grabelis (5 ha), Kaušys (5 ha), Aikuotas (5 ha), Demenas (5 ha), Sniegiškis (5ha), Galminių ež. (5 ha), Dubužis (4 ha), Lydekis (3 ha), Kanapelkis (2 ha) ir penki neįvardyti mažesni ežerèliai. Deja, šios teritorijos pirminio kartografavimo žemèlapių iki karo, po kurio prarasta Lietuvos nepriklausomybè, išleisti nebespèta.

Elektrènu 1264 ha ploto tvenkinys ant Strèvos upès buvo i̇rengtas $1961 \mathrm{~m}$. šiluminès elektrinès reikmèms [2]. Jis aprèpé Anykščių (192 ha), Punkino (79 ha), Jagudžio (38 ha), Pernokès (5 ha) ir Nendrinèlio (3 ha) ežerus. Šiuos ežerus jungiant $\mathfrak{i}$ bendrą tvenkini dalies ežeru išoriniai krantų kontūrai išliko.

Traku rajone $1960 \mathrm{~m}$. patvenkus Verknę hidroelektrinès reikmèms buvo irengtas Aukštadvario 174 ha tvenkinys (1 pav.) Jis sujungè Baluosio (20 ha), Baluosèlio (5,5 ha), Baluosiuko (2,5 ha) ir Negasčiaus bei Navos (kartu 120 ha) ežerus (2 pav.), tačiau jų stačių krantų išoriniai kontūrai iš dalies išliko. 


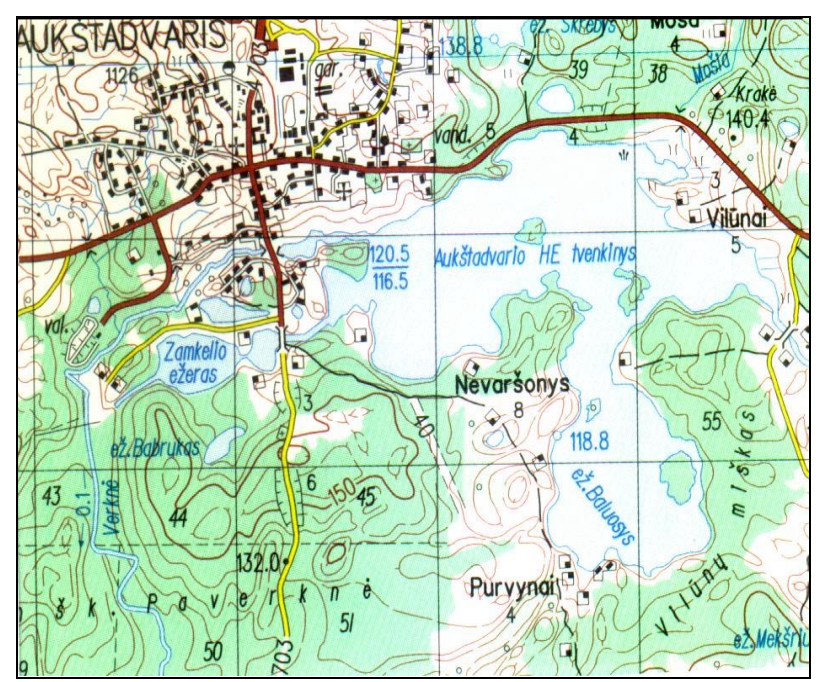

1 pav. Topografinio M 1:50 000 žemėlapio AUKŠTADVARIS 65-69/25-29 fragmentas, $2003 \mathrm{~m}$.

Fig 1. Fragment of the map AUKŠTADVARIS 65-69/25-29. 1:50 000, 2003

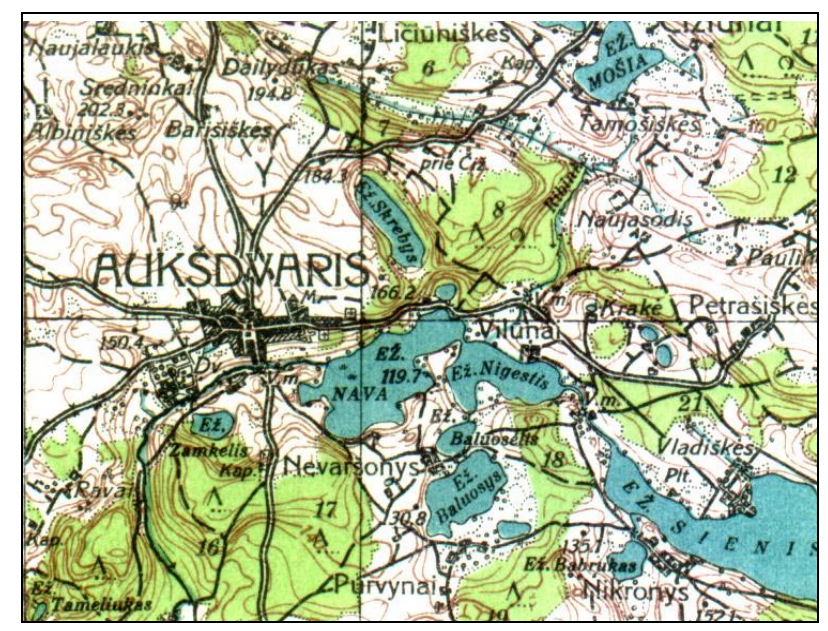

2 pav. Topografinio M 1:100 000 žemèlapio 1707 AUKŠTADVARIS - TRAKAI fragmentas, $1937 \mathrm{~m}$. (padidintas $1,3^{\mathrm{X}}$ )

Fig 2. Fragment of the topographical map 1707 AUKŠTADVARIS - TRAKAI. 1:100 000, 1937 (enlarged 1,3 time)

Tais pačiais metais Trakų rajone hidroelektrinès poreikiams ant Strèvos irengtas 96 ha Bagdononiu tvenkinys (3 pav.) sujungè Strèvio (14,4 ha), Strèvaičio (3,7 ha), Nepèro (17,8 ha), Eglio (6,7 ha) ir Gilūšio ( 8,2 ha) ežerus (4 ir 5 pav.) [3].

Bubių tvenkinys ant Dubysos ir Ringuvos upių ( $\approx 6 \mathrm{~km}$ i pietvakarius nuo Šiauliu) sujunge Jonelaičių (25,8 ha) ir Raizgiu (Balnius, 8,1 ha) ežerus [4, 5].

Arimaičių ežeras (290 ha) dèl patvankos apie $5 \mathrm{~km} \mathrm{i}$ vakarus nuo Šeduvos susijungè su Žirnio (Paežeriu) ežeru (7,2 ha), nutolusiu nuo Arimaičių pirminio ežero (43,5 ha), (inv. Nr. 16-2) apie $2 \mathrm{~km}$ atstumu [4, 5].

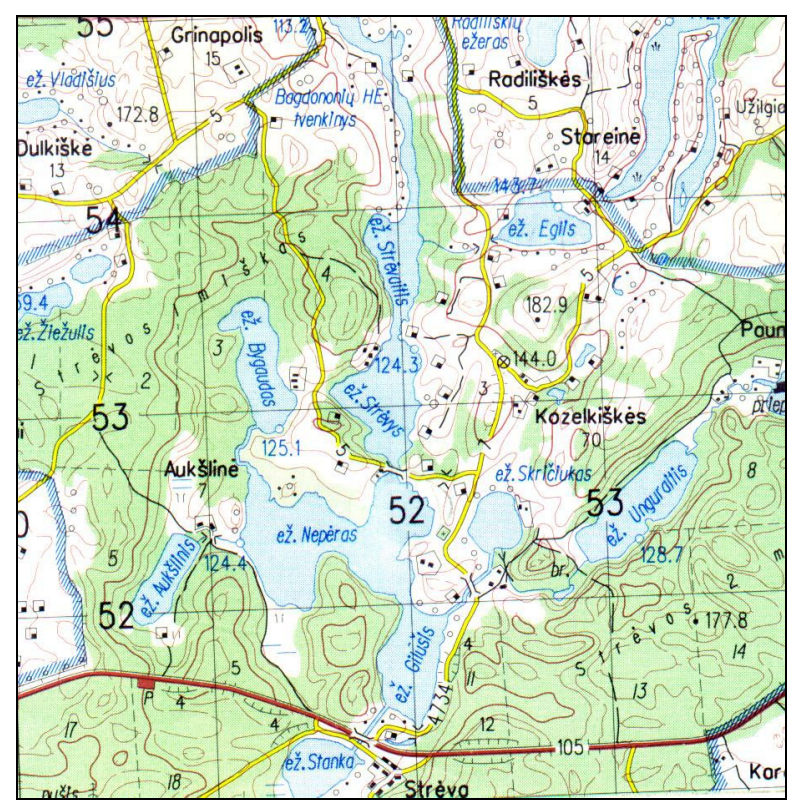

3 pav. Topografinio M 1:50 000 žemėlapio TRAKAI N-35-50AB fragmentas. Bagdononių tvenkinys, $1998 \mathrm{~m}$.

Fig 3. Fragment of the topographical map TRAKAI N-35-50AB for Bagdononiu pond. 1:50 000, 1998

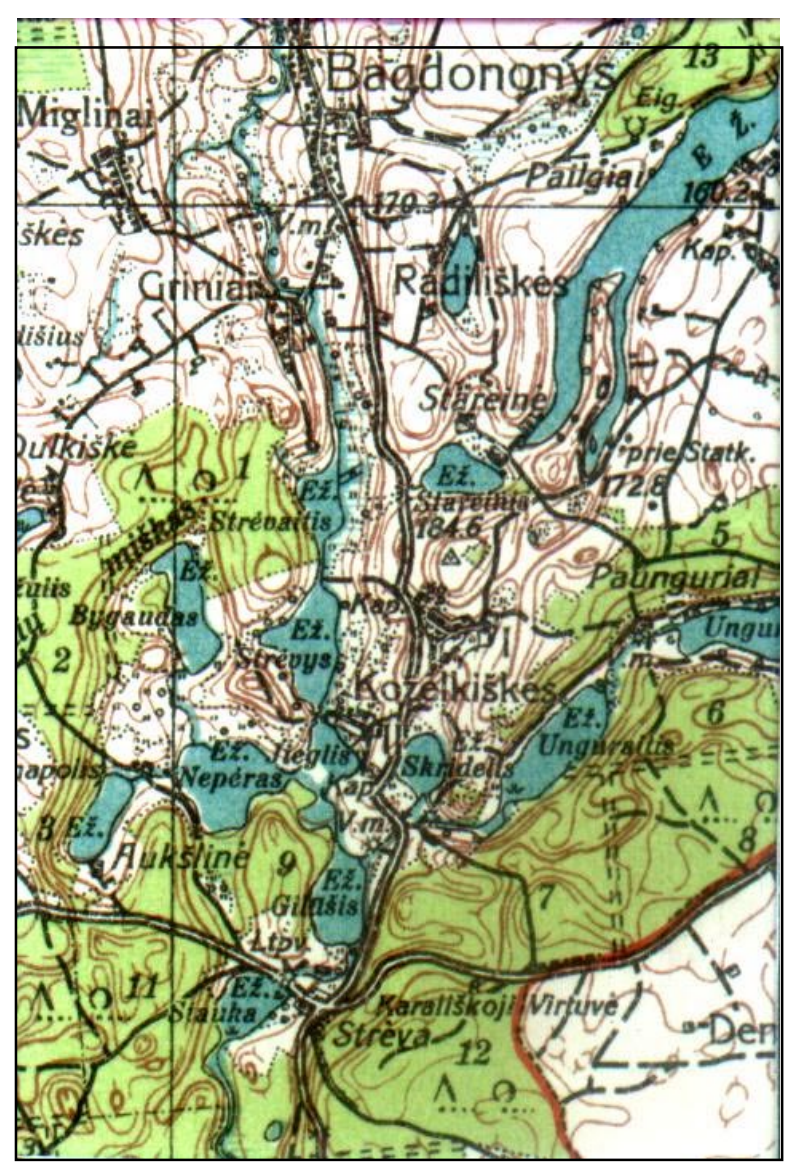

4 pav. Topografinio M 1: 100000 žemėlapio 1707 AUKŠTADVARIS - TRAKAI fragmentas, 1937 m. (padidintas $1,6^{\mathrm{X}}$ )

Fig 4. Fragment of the topographical map 1707 AUKŠTADVARIS - TRAKAI. 1: 100 000, 1937 (enlarged 1,6 time) 


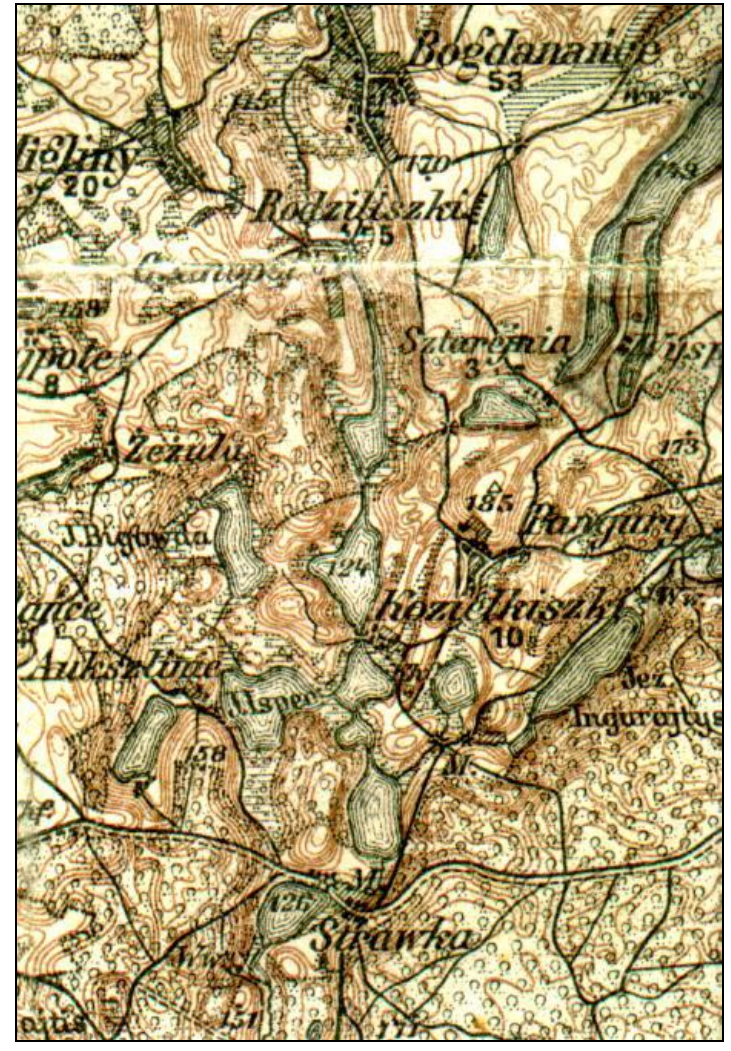

5 pav. Vokiečių M 1:100 000 topografinio žemėlapio P 23 Sumiliszki (Karte des westlichen Russlands) fragmentas, (padidintas $1,7^{\mathrm{X}}$ )

Fig 5. Fragment of the German topographical map P 23 Sumiliszki (Karte des westlichen Russlands). 1:100 000 (enlarged 1,7 time)

Alytaus rajone greta Ūdrijos gyvenvietès esantis 140 ha ežeras kartografineje medžiagoje yra vadinamas Kavaliu (inv. Nr. 55-39) arba Dusele. Pirminio kartografavimo žemélapiuose abu pavadinimai i̇vardija skirtingas ežero dalis, besijungiančias sąsmauka (vakarinè dalis - Kavalys, rytinè dalis - Duselè) [4], todèl dabar jis priskirtas prie dvivardžiu ežerų. Dvivardžiu ežerų kategorijai priklauso daug ežerų, kurių vardai, fiksuoti atliekant pirmaji kartografavima, vèliau buvo pakeisti. Informacija apie šiuos ežerus teikiama lentelëje.

Tenka pripažinti, kad atliekant antraji kartografavima, nepaisant stambesnio mastelio, prarasta smulkesnių ežerèlių būdingų vardų, teiktų kartografuojant pirmąkart. Pvz., Pumpuriukas (inv. Nr. 15-41), Lukštynė (inv. Nr. 35-17), Nemuno senvagès ež. (inv. Nr. 35-16), Dumblikas (inv. Nr. 50-86), Bingutè (inv. Nr. 62-76), Katiliukas (inv. Nr. 55-2), Aklys (inv. Nr. 62-81), Medvėkas (inv. Nr. 62-79) ir kt. [4]. Taigi prarandamos hidronimų lokalizavimo galimybès.

Antra vertus, atliekant antraji kartografavimą ivardyti kiti smulkūs ežeriukai, kurių vardai nebuvo nustatyti kartografuojant pirmą kartą. Pvz., Anaičiu ež. (inv. Nr.11-3), Plazè (inv. Nr. 11-1), Medainis (inv. Nr. 149), Dubènų ež. (inv. Nr. 14-11), Žalgirių ež. (inv. Nr. 418), Vašuokẻnų ež. (inv. Nr. 29-2), Bulotų ež. (inv. Nr.
17-10), Plūsčia (inv. Nr. 25-4), Visgaudų ež. (inv. Nr. 25-3) [5].

\section{Ežerų vardų norminimas}

I lentelę neitraukti ežeru pavadinimai, kurių pokyčiai siejasi su norminimu. Pvz., Užrè - Užris (inv. Nr. 13-4), Žeizdis - Žiezdis (inv. Nr. 13-30), Talšos ež. - Talkša (inv. Nr. 15-11), Rekijavas - Rekyvos ež. (inv. Nr.1514), Antakmenių ež. - Akmena (inv. Nr. 50-12) ir pan. [6].

Teigtina, kad norminant vardus ir nesiejant pavadinimo su geografine aplinka, padaryta ir abejotinu sprendimų. Pvz., Oplankio ežeras (inv. Nr. 36-6) šalia Oplankio kaimo 1938 m. atliekant pirmaji kartografavimą buvo ivvardytas Uplankio ežeru, o kaimas - Uplankiu (6 pav.). Šie vardai buvo siejami su Jūros kilpiniu išlinkiu, šalia kurio yra gyvenvietè ir ežeras. A. Vanagas Oplankio vardo etimologiją sieja su „aplanka, išlenkimas, vingis“ [7].

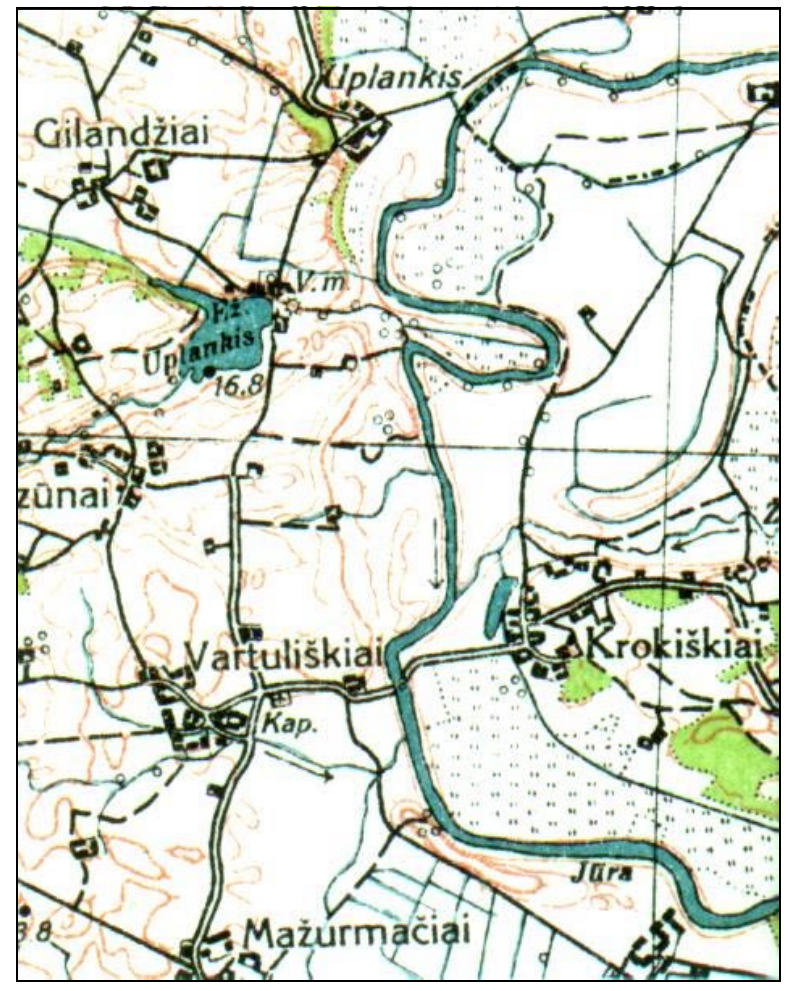

6 pav. Topografinio M $1: 100 \quad 000$ žemèlapio 1502 VILKYŠKIAI -VIEŠVILĖ fragmentas, $1938 \mathrm{~m}$. (padidintas $2^{\mathrm{X}}$ ) Fig 6. Fragment of the topographical map 1502 VILKYŠKIAI VIEŠVILE். 1:100 000, 1938 (enlarged 2 times)

Šerniukšnynu ivardytas 3 ha ežeras $1939 \mathrm{~m}$. pirminio kartografavimo lape 1204 KURTUVĖNAI ŚIAULIAI buvo siejamas su „šerniukais“ pagal panašia analogiją su greta esančio ežero vardu Barsukynas (inv. Nr. 15-28). Tad upių ir ežerų vardyne [6] iteisintas ežero (inv. Nr. 15-29) prasminis vardas Šermukšnynas nesietinas su jo charakteristika, nes ežero aplinka supelkejjusi. 
Dviejų kartografavimo etapų ežerų vardų pokyčiai

Changes of the names of lakes during two cartographer periods

\begin{tabular}{|c|c|c|c|}
\hline $\begin{array}{c}\text { Ežero } \\
\text { inventorinis Nr. } \\
{[8]}\end{array}$ & Pirminis ir antrinis vardai $[4,5]$ & Vardo sąsaja [7] & $\begin{array}{l}\text { Kartografavimo lapai } \\
{[4,5]}\end{array}$ \\
\hline $13-2$ & $\begin{array}{l}\text { Bimbalinė } \\
\text { Judrinas }\end{array}$ & $\begin{array}{l}\text { Bimbalas - sparva } \\
\text { upé Judra }\end{array}$ & $\begin{array}{l}1202 \text { Telšiai-Žarènai } \\
\text { Telšiai N-34-9-AB }\end{array}$ \\
\hline $13-32$ & $\begin{array}{l}\text { Milvydo ež. } \\
\text { Gūšra }\end{array}$ & $\begin{array}{l}\text { km. Milvydiškiai } \\
\text { upe Druja (Gūšra) }\end{array}$ & $\begin{array}{l}1202 \text { Telšiai-Žarènai } \\
\text { Varniai N-34-9-CD }\end{array}$ \\
\hline $18-7$ & $\begin{array}{l}\text { Jurgiškių ež. } \\
\text { Suosa } \\
\end{array}$ & $\begin{array}{l}\text { km. Jurgiškis } \\
\text { upė Suosa }\end{array}$ & $\begin{array}{l}1307 \text { Raguva-Troškūnai } \\
\text { Subačius N-35-2-CD }\end{array}$ \\
\hline $25-14$ & $\begin{array}{l}\text { Noruišiu ež. } \\
\text { Sustojus }\end{array}$ & $\begin{array}{l}\mathrm{km} \text {. Noruišiai } \\
\text { sustoti - liautis judèti }\end{array}$ & $\begin{array}{l}1303 \text { Kražiai-Kelmè } \\
\text { Kelmè N-34-22-AB }\end{array}$ \\
\hline $26-15$ & $\begin{array}{l}\text { Tamošiškių ež. } \\
\text { Juodežeris }\end{array}$ & km. Tamošiškiai & $\begin{array}{l}\text { 1304 Šiluva-Šiaulènai } \\
\text { Tytuvėnai N-34-23-AB }\end{array}$ \\
\hline $28-3$ & $\begin{array}{l}\text { Gudelių ež. } \\
\text { Lieležeris } \\
\end{array}$ & $\begin{array}{l}\mathrm{km} . \text { Gudeliai } \\
\text { lielas - didelis }\end{array}$ & $\begin{array}{l}1306 \text { Krekenava-Panevėžys } \\
\text { Ramygala N-35-13-AB }\end{array}$ \\
\hline $29-9$ & \begin{tabular}{|l|} 
Šilų ež. \\
Enčias \\
\end{tabular} & $\begin{array}{l}\text { km. Šilai } \\
\text { nuo ,antis“ }\end{array}$ & $\begin{array}{l}\text { 1407 Siesikai-Kavarskas } \\
\text { Kavarskas N-35-14-CD }\end{array}$ \\
\hline $35-11$ & $\begin{array}{l}\text { Pagègiu ež. } \\
\text { Velnežeris }\end{array}$ & mst. Pagègiai & $\begin{array}{l}\text { 1501 Paleičiai-Pagègiai } \\
\text { Pagėgiai N-34-32-CD }\end{array}$ \\
\hline $40-6$ & $\begin{array}{l}\text { Bronislavos ež. } \\
\text { Baltas } \\
\end{array}$ & asmenvardis & $\begin{array}{l}1506 \text { Žeimiai-Jonava } \\
\text { Jonava N-35-25-CD }\end{array}$ \\
\hline $40-7$ & $\begin{array}{l}\text { Kryžiaukos ež. } \\
\text { Juodas }\end{array}$ & km. Kryžiauka & $\begin{array}{l}1506 \text { Žeimiai-Jonava } \\
\text { Jonava N-35-25-CD }\end{array}$ \\
\hline $41-28$ & $\begin{array}{l}\text { Prienų ež. } \\
\text { Stavarygalos ež. }\end{array}$ & $\begin{array}{l}\text { km. Prienai } \\
\text { km. Stavarygala }\end{array}$ & $\begin{array}{l}1507 \text { Ukmergè-Širvintos } \\
\text { Širvintos N-35-26-CD }\end{array}$ \\
\hline $50-6$ & $\begin{array}{l}\text { Lungis } \\
\text { Abromiškių ež. }\end{array}$ & $\begin{array}{l}\text { Lungis - sulinkęs } \\
\mathrm{km} \text {. Abromiškès }\end{array}$ & $\begin{array}{l}\text { 1607 Žasliai -Kernavė } \\
\text { Elektrėnai N-35-38-D }\end{array}$ \\
\hline $50-10$ & $\begin{array}{l}\text { Dubuklis } \\
\text { Geibonių ež. }\end{array}$ & $\begin{array}{l}\text { Dublus - dubus } \\
\text { km. Geiboniai }\end{array}$ & $\begin{array}{l}1607 \text { Žasliai -Kernavė } \\
\text { Elektrėnai N-35-38-CD }\end{array}$ \\
\hline $50-45$ & $\begin{array}{l}\text { Gadėnas } \\
\text { Gelvaitis } \\
\end{array}$ & $\begin{array}{l}\text { asmenvardis } \\
\text { mažybinis nuo „galvio“ }\end{array}$ & $\begin{array}{l}1707 \text { Aukštadvaris-Trakai } \\
\text { Elektrėnai N-35-38-D }\end{array}$ \\
\hline $50-77$ & $\begin{array}{l}\text { Aliosės } \\
\text { Ausieniškių ež. }\end{array}$ & $\begin{array}{l}\text { up. Aliosa } \\
\text { km. Ausieniškès }\end{array}$ & $\begin{array}{l}1607 \text { Žasliai-Kernavė } \\
\text { Elektrènai N-35-38-CD }\end{array}$ \\
\hline $50-119$ & $\begin{array}{l}\text { Galgaičių ež. } \\
\text { Ilgučiai }\end{array}$ & galginas - žąsinas & $\begin{array}{l}1707 \text { Aukštadvaris-Trakai } \\
\text { Elektrėnai N-35-38-CD }\end{array}$ \\
\hline $50-129$ & $\begin{array}{l}\text { Gapuškių ež. } \\
\text { Epušès }\end{array}$ & epušè - drebulè & $\begin{array}{l}1707 \text { Aukštadvaris-Trakai } \\
\text { Elektrènai N-35-38-D }\end{array}$ \\
\hline $50-130$ & $\begin{array}{l}\text { Pervalonys } \\
\text { Šulininkų ež. }\end{array}$ & km. Šulininkai & $\begin{array}{l}1707 \text { Aukštadvaris-Trakai } \\
\text { Elektrėnai N-35-38-CD }\end{array}$ \\
\hline $50-137$ & $\begin{array}{l}\text { Kunigiškiu ež. } \\
\text { Birva }\end{array}$ & km. Birva & $\begin{array}{l}1707 \text { Aukštadvaris-Trakai } \\
\text { Elektrėnai N-35-38-CD }\end{array}$ \\
\hline $51-78$ & $\begin{array}{l}\text { Dėdeliškių ež. } \\
\text { Žuraviškių ež. }\end{array}$ & km. Dėdeliškès & $\begin{array}{l}\text { 1708 Lentvaris-Trakai } \\
\text { Vilnius N-35-39-CD }\end{array}$ \\
\hline $56-18$ & $\begin{array}{l}\text { Pieštuvėnų ež. } \\
\text { Alšia } \\
\end{array}$ & $\begin{array}{l}\text { km. Pieštuvėnai } \\
\text { up. Alšia }\end{array}$ & $\begin{array}{l}1706 \text { Birštonas-Stakliškès } \\
\text { Birštonas N-35-49-AB }\end{array}$ \\
\hline $56-35$ & \begin{tabular}{|l|} 
Stankis \\
Gudžionių ežerai \\
\end{tabular} & km. Gudžionys & $\begin{array}{l}1706 \text { Birštonas-Stakliškès } \\
\text { Birštonas N-35-49-AB } \\
\end{array}$ \\
\hline $57-72$ & $\begin{array}{l}\text { Bebrukas } \\
\text { Mekšriukas } \\
\end{array}$ & mekšras - kuoja & $\begin{array}{l}1707 \text { Aukštadvaris-Trakai } \\
\text { Trakai N-35-50-AB }\end{array}$ \\
\hline $58-9$ & $\begin{array}{l}\text { Lygainiu ež. } \\
\text { Ilgutis } \\
\end{array}$ & km. Lygainès & $\begin{array}{l}1708 \text { Lentvaris -Vilnius } \\
\text { Vilnius (pietinè dalis) N-5-51-AB }\end{array}$ \\
\hline $60-9$ & $\begin{array}{l}\text { Kybartų ež. } \\
\text { Ilgelis }\end{array}$ & km. Kybartai & $\begin{array}{l}\text { 1804 Kalvarija-Šeštokai } \\
\text { Rudamina N-34-71-AB }\end{array}$ \\
\hline $61-63$ & $\begin{array}{l}\text { Pragarinès ež. } \\
\text { Kernavės ež. }\end{array}$ & $\begin{array}{l}\text { raistas Pragarinė } \\
\text { mst. Kernavė }\end{array}$ & $\begin{array}{l}1607 \text { Žasliai-Kernavė } \\
\text { Žasliai N-35-38-AB }\end{array}$ \\
\hline $61-75$ & $\begin{array}{l}\text { Geišiškių ež. } \\
\text { Aliejūnų ež. }\end{array}$ & $\begin{array}{l}\mathrm{km} \text {. Geišiškès } \\
\mathrm{km} \text {. Aliejūnai }\end{array}$ & $\begin{array}{l}1607 \text { Žasliai-Kernavė } \\
\text { Žasliai N-5-38-B }\end{array}$ \\
\hline $62-69$ & $\begin{array}{l}\text { Raistinis } \\
\text { Bedugnè } \\
\end{array}$ & & $\begin{array}{l}\text { 1806 Alytus-Daugai } \\
\text { Perloja N-35-61-AB }\end{array}$ \\
\hline $62-80$ & \begin{tabular}{|l|} 
Ilgis \\
Ežeriekų ež. \\
\end{tabular} & km. Ežeriekai & $\begin{array}{l}\text { 1806 Alytus-Daugai } \\
\text { Perloja N-35-61-AB }\end{array}$ \\
\hline
\end{tabular}


Nesusiejimas su aplinka akivaizdus ir Vardyne [6] norminant ežero Beržinis vardą (inv. Nr. 32-63). Vardyne nurodyta jo lokalizacija - Smalvas, Beržynès viensèdis - yra klaidinantis, nes vienkiemis vadintas Paberžone nuo ežero Beržona, ivvardyto $1932 \mathrm{~m}$. lenkų išleistame okupuotos Lietuvos teritorijos M 1:100 000 žemėlapyje Dukszty [9]. Šalia vienkiemio greta telkšo du skirtingo dydžio ežerai $(\approx 20$ ha ir $\approx 1$ ha). Mažesnis ežeras, atliekant antraji kartografavimą, ivvardytas Paberžuone, o didysis, susisiejantis su Beržonių pelke, turètų vadintis Beržonis ar Beržuonis pagal vienkiemio ar pelkès vardą. Tačiau iš to paties pavadinimo kilę vietovardžiai teikiami skirtingai: vienkiemis Paberžuonè, pelkè - Beržonių, o ežeras - Beržinis.

Žemiau Bagdononių tvenkinio atliekant pirmaji kartografavimą (4 pav.) ìvardytas ežeras Stauka, kartografuojant antraji kartą (3 pav.), tapo Stanka (inv. Nr. 57-96). Kalbininkai iki šiol šio 9,2 ha dydžio ežero vardo nesièmè norminti. Šio ežero pavadinimo kilmè sietina su paežerèje issikūrusia per Pirmaji pasaulini karą kartografuota gyvenviete Cтраwka (5 pav.) [10]. Jos pavadinimas kilęs nuo tuo laikmečiu kartografuotos upès Strèvos (Стpawa). Tad teigtina, kad kartografuojant pirmaji ir antraji kartą iškreipti ežero pavadinimai norminant turètų būti susieti su Strèvos vardu.

Lietuvių kalbos instituto kalbininkai parengè, o Mokslo ir enciklopediju leidybos institutas $2002 \mathrm{~m}$. išleido sunormintų vietovardžių žodyną [11]. Leidinys apima ir didesnių nei 10 ha ploto ežerų vardus. Kadangi apie penktadalis inventorizuotų Lietuvos ežeru yra tokio dydžio, ir dauguma jų ivvardyti, tai leidinys tik iš dalies patenkino ežerų norminimo reikmę.

\section{Išvados}

1. Ežerų dvivardiškumas sietinas ir su dviem skirtingo laikmečio kartografavimais.

2. Pletojantis Lietuvos melioracijai ir energetikai sovietmečiu buvo irengta tvenkinių, kurie apsèmè ežerus arba pakeitè ežerų krantus.

3. Kartografuojant antrą kartą daug ežerų vardu sunorminta, pataisant tarmiškumą, keičiant vietovardžio giminę, paprastai i vyrišką ir pan.

4. Kalbininkai, normindami ežeru vardus, nesiejo jų su vietovardžių geografine aplinka, tad pasitaiko abejotinų norminimo atvejų.

5. Atliekant antraji kartografavimą prarasta dalis mažų ežerų vardų, nors kartografavimo mastelis viena eile stambesnis. Antra vertus, ivvardyta ir dalis mažu ežeriukų, kurie kartografuojant pirmą kartą neturejjo vardų.

6. Kalbininkai nèra oficialiai sunorminę dalies ežerų pavadinimų, o tik kartografuojant antrą kartą atlikę jų aplinkos vietovardžių ekspertizę.

\section{Literatūra}

1. Kaunas lagoon (Kauno marios). Lietuvos TSR paminklu apsaugos ir kraštotyros draugija. Vilnius: Mokslas, 1980, p 70; 470 (in Lithuanian)

2. Short Lithuanian soviet encyclopaedia (Mažoji lietuviškoji tarybine enciklopedija). Vol 1, Vilnius: Mintis, 1966, p 70; 470 (in Lithuanian).

3. List of Lithuanian lakes (supplied by morphometric data) (Lietuvos ežeru sąrašas (su morfometriniais duomenimis). Republican water economy design institute, Kaunas, 1964 (in Lithuanian).

4. Maps M 1:100 000 of the First Lithuanian mapping period (Pirmojo lietuviško topografinio kartografavimo M1:100 000 žemèlapiai). Military topography department, 1933-1940.

5. Maps M 1:50 000 of the Second Lithuanian mapping period (Antrojo lietuviško topografinio kartografavimo M1:50 000 žemėlapiai). VGKT, 1997-2003.

6. Index of proper names of Lithuania SSR rivers and lakes (Lietuvos TSR upių ir ežerų vardynas). Institute of Lithuanian language and literature, State publishing house of political and scientific literature, Vilnius, 1963 (in Lithuanian).

7. Vanagas, A. Ethymologic dictionary of Lithuanian hydronims (Lietuvių hidronimų etimologinis žodynas). Vilnius: Mokslas, 1981 (in Lithuanian).

8. Classificator of Lithuanian Republic lakes (Lietuvos Respublikos ežeru klasifikatorius). Valstybès žinios, Nr. 34-1442, 20030409 (in Lithuanian).

9. Polish topographic map M 1:100 000, published in 1932 (1932 metais lenku išleistas M 1:100 000 topografinis žemèlapis). PAS 26; SLUP 43 Dukszty.

10. German topographic map of the period of WWI (Pirmojo pasaulinio karo laikmečio vokiečių topografinis žemėlapis). P 23 Sumiliszki, Karte des westlichen Russlands.

11. Dictionary of geographic names (Vietovardžių žodynas. Sudare A. Pupkis ir M. Razmukaite, Mokslų ir enciklopediju leidybos institutas), 2002, p 5 (in Lithuanian). 